\title{
The impact of Foreign Direct investment on economic growth: The case of Zimbabwe (2009- 2012)
}

\author{
Tinomuonga Moyo \\ Great Zimbabwe University, Department of Banking \& Finance
}

Email address:

tinomuongamoyo@gmail.com,office@mfnlifting.co.za

\section{To cite this article:}

Tinomuonga Moyo. The Impact of Foreign Direct Investment on Economic Growth: The Case of Zimbabwe (2009- 2012). International Journal of Economics, Finance and Management Sciences. Vol. 1, No. 6, 2013, pp. 323-329. doi: 10.11648/j.ijefm.20130106.19

\begin{abstract}
This paper analyzes the impact of Foreign Direct Investment on GDP in Zimbabwe, post dollarization period. Foreign Direct Investment has very significant positive impact on economic growth. I advocate for policies that promote inward FDI if our country is to meet its economic growth targets. The paper also analyses the impact of other macro economic factors on Gross Domestic product. Government Expenditure and Private Investment is found to have significant and positive impact on Gross Domestic Product. Factors that are found to affect GDP negatively are increases in Inflation and Interest Rates. The Zimbabwean data was inconclusive on the impact of two factors on Economic Growth, Which is External Debt and Net Exports; this merits further research because it is not in line with the theoretical predictions.
\end{abstract}

Keywords: Foreign Direct Investment, Gross Domestic Product, Inflation, External Debt, Net exports, Private Investment

\section{Introduction}

FDI has many forms. Broadly, FDI includes mergers and acquisitions, building new facilities, renovating profits from overseas operations and intra company loans. In narrow sense FDI refers to building new facilities. The numerical FDI figures based on varied definitions are not easily comparable. Its contribution to national income equation is easily identifiable: $\mathrm{Y}=\mathrm{C}+\mathrm{I}+\mathrm{G}+(\mathrm{X}-\mathrm{M})$

"I" resemble investment plus foreign investment.FDI is defined as the net inflows of investment. Inflows minus outflows to acquire a lasting management interest [10\%or more of voting stock] in an enterprise operating in an economy other than that of an investor (World Bank; 2012). It usually involves participation in management, joint venture, transfer of technology and enterprise. FDI is an example of international factor movements. There are three types of FDI, these are: Horizontal FDI (Firm duplicates its home country based activities of the same value chain stage in the host country through FDI.) Secondly, Platform FDI and Lastly Vertical FDI which takes place when a firm through FDI moves upstream or downstream in different value chains, that is, when firms perform value adding activities, stage by stage in a vertical fashion in a host country. A recent analyst of the effects of FDI on local firms in developing and transaction countries suggests that
FDI robustly increases local productivity growth (Havranek T. et al 2011). The commitment to development index ranks the "development friend liners" of rich country investment policies.

\section{Background to the Study}

Zimbabwe once touted the Jewel of Africa at Independency in 1980, has over the years acquired a reputation of as the stickman of Southern African region, with disastrous economic policies, political instability and peculiar inability to get itself out of often self-inflicted difficulties (I. Bayai et al; 2013). United Nations Conference on trade and development (UNCTAD; 2000) estimated that in order to reach sustainable economic growth rate of $6 \%$ per annum, the domestic investment levels in the Sub Saharan Africa (SSA) have to increase to about $25 \%$ from the levels reached during the 1990s of less than $20 \%$. As such foreign capital is regarded as very crucial in bridging the resource gap created by the shortage of savings in these developing countries.

The United States of America was the world's largest recipient of FDI in 2010 before being overtaken by China in 2012. The US FDI totaled $\$ 194$ billion in $2010,84 \%$ of FDI in the US in 2010 came from or through eight countries namely Switzerland, the United Kingdom, Japan, France ,Germany ,Luxembourg, the Netherlands and 
Canada ( Greyhill Advisors, 2011). Research shows that foreigners hold greater shares of their investment portfolio in the United States if their own countries have less developed financial markets, an effect whose magnitude decreases with income per capita. White house data reported in June 2011 found out that a total of 5,7 million workers were employed at facilities highly dependent of foreign direct investors. Thus about $13 \%$ of the American manufacturing workforce depended on such investment.

FDI in China, also known as RFDI (Renminbi Foreign Direct Investment), has increased considerably in the last decade, reaching $\$ 59,10$ billion in the first six months of 2012 ,making China the largest recipient of FDI and topping the United States which had $\$ 57,4$ billion of FDI (UN Agency 2012-10-24). Data from China shows that GDP has been growing and falling with FDI during the global financial crisis ,FDI fell by over one -third in 2009 but rebounded in 2010 [Grey Hill Advisors 2011]

FDI is often referred to as a vehicle of technical progress. By introducing advanced technology, management practices and improved production techniques, it is argued that FDI can improve productivity (Borensztein et al 1998). Foreign direct investment has been the major economic driver in developing countries such as Ghana and Parkstan (Haroon et al 2011). Growth enhancing factors of FDI depends on the absorptive capacity of the recipient country which in turn depends on the educational levels and the development of the financial markets among other factors (Gwenhamo 2009)

Empirical evidence from developed and developing world show that FDI plays a very important role in improving economic growth together with its sister factors, that is, Private investment and public investment. Lessons from India Shows loose policies on FDI with some sectors allowed more than $100 \%$ of FDI.

Also the background will be incomplete if I do not look at the trends in FDI and GDP at post independency era. At the time of independency, the newly elected government of Zimbabwe adopted a highly controlled and inward looking economy that heavily depended on $\operatorname{FDI}(70 \%)$ on the promotion of economic growth (Clarke 1980). Ownership restrictions in some sectors required at least 30\% local participation in an enterprise (Gwenhamo; 2009). There have been a lot of policies to hinder repatriation of profits in the post independency era which reduced the much desired FDI in the economy.

In the late 1980s, Zimbabwe adopted a new investment code that saw MNCs being allowed to repatriate $50 \%$ to $100 \%$ of the profits (Ibid; 2009). In 1990 the government adopted ESAP (Economic structural Adjustment Program) that was meant to eradicate polices of economic restrictions. Year 1992 saw the establishment of ZIC (Zimbabwe Investment Centre) in order to handle and coordinate investment approvals (IMF 1992). This saw a lot of incentives being put forward to increase FDI, for example tax holidays and tariff exemptions were offered to encourage foreign capital investments, technological transfer, utilization of local raw materials, and development of rural areas and the use of labor intensive production techniques. This resulted in an increase of FDI that averaged above \$50million between 1990 and 1997; year 1998 recorded the highest FDI of US\$444 million (IMF 1998).

Investment by firms from South African was the highest in 1998. Investor confidence was however dissolved by political instability in late 1990; this was worsened by the compulsory farm acquisition of year 2000. Jechere (2011) Noted that Zimbabwe made the least progress of all SADC countries on this front. On the doing business indicators, Zimbabwe moved only two points between 2008 and 2010, Botswana moved by 15 points. Data from IMF shows the fall in FDI coupled by a fall in GDP on year to year basis

\section{Research Methodology}

Newman et al (1998) stated that people claimed that only by holding onto the quantitative traditions we can have confidence in our knowledge base. Along with other behavioral researchers I tend to agree with Newman's assertion. The paradigm of positivism (quantitative research) continues to dominate social and behavioral science. It is steeped in historical tradition.

Mamia (1992) asserted that quantitative methods are ideal where a phenomenon can be quantified, measured and expressed numerically. Thus quantitative research is the most appropriate method to analyse the variables such as FDI and Economic growth etc. Quantitative design enables research and description of economic problems and processes that are not directly observable (Bayai et al 2013). They said that it is well suited for quantitative description; comparisons between groups, areas or variables.

Two models shall be tested in this model. The first model shall link FDI to economic growth and the second model shall link all macroeconomic variables to economic growth, (FDI inclusive) in the Bid to uncover other factors affecting economic growth in the economy.

Model 1

$$
\begin{aligned}
& \mathrm{g}_{\mathrm{Yi} ; \mathrm{t}}=\alpha+\beta \mathrm{g}_{\mathrm{Fi} ; \mathrm{t}}+\mathrm{E} \\
& \text { Model } 2 \\
& \mathrm{~g}_{\mathrm{Y}}=\mathrm{g}_{\mathrm{A}}+\beta_{1} \mathrm{~g}_{\mathrm{F}}+\beta_{2} \mathrm{~g}_{\mathrm{GE}}+\beta_{3} \mathrm{~g}_{\mathrm{INF}}+\beta_{4} \mathrm{~g}_{\mathrm{IR}}+\beta_{5} \mathrm{~g}_{\mathrm{ED}}+\beta_{6} \mathrm{~g}_{\mathrm{NE}}+ \\
& \beta_{7} \mathrm{~g}_{\mathrm{PI}}+\mathrm{E}
\end{aligned}
$$

\section{Data Presentation and Analysis}

The chapter presents regression results obtained using Eviews 4(2). The process involves stationary test that is done using the Augmented Dickey-Fuller (ADF) test. An interpretation to each and every explanatory variable is done using the coefficients, $\mathrm{t}$-statistic and the probability of hypothesis rejection. The value of $\mathrm{R}^{2}$ and adjusted $\mathrm{R}^{2}$ is used to determine tolerance factor in order to detect multicollinearity. The Durbin-Watson Statistic will be used to detect the presence of autocorrelation. Covariance matrix will be used to measure how variables change together. The 
sign of the covariance show the tendency in the linear relationship. The magnitude of the strength of the linear relationship will be determined by the correlation coefficient.

\section{Stationary of Variables}

According to Badawi(2003), the equation should be estimated at a level where variables are stationary. The Augmented Dickey-Fuller test was use to test the level at which the variables are stationary, this paves way for the regression equation upon which the results of the research shall be built.

Table 4.0. Summarizes stationary test of variables

\begin{tabular}{|c|c|c|c|c|}
\hline Variable & ADF Statistic & Mackinnon Variable & Order of Integration & Decision Rule \\
\hline GDP & $-11.46242^{*}$ & -3.5745 & 0 & Stationary at $1 \%$ \\
\hline FDI & $2.083033^{*}$ & -3.5745 & 0 & Stationary at $1 \%$ \\
\hline GVT EXP & $-2.029611^{*}$ & -3.5778 & 1 & Stationary at $1 \%$ \\
\hline INFLATION & $-9.266929 *$ & -3.5745 & 0 & Stationary at $1 \%$ \\
\hline INT. RATE & $-2.062040^{*}$ & -3.5745 & 0 & Stationary at $1 \%$ \\
\hline EXT. Debt & $-4.646740 *$ & -3.5778 & 1 & Stationary at $1 \%$ \\
\hline Net Exports & $-5.871179 *$ & -3.5778 & 1 & Stationary at $1 \%$ \\
\hline Priv. Investment & $-4.382423 *$ & -3.5745 & 0 & Stationary at $1 \%$ \\
\hline
\end{tabular}

Source: Appendix 2 (Unit Root Test)

\section{Decision rule Illustration}

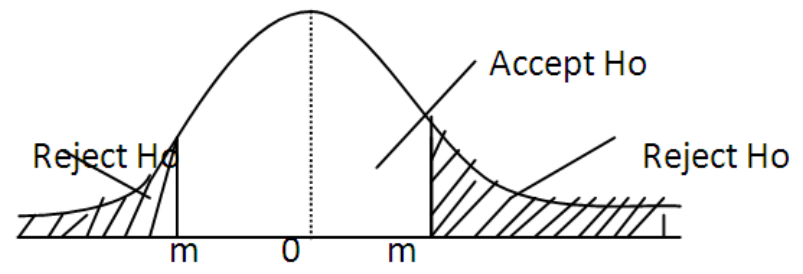

Then GDP is stationary at level. The ADF statistic is -11 , 46242 and the decision rule (Mackinnon value) is -3.5745 at $1 \%$. I therefore reject the null hypothesis and conclude that there is a unit root on the gross domestic product. I also conclude that GDP is stationary at level at 99\% level of confidence. The FDI is also stationary at level. The ADF statistic is 2.083033 against a Mackinnon value of -3.5745 . I do not reject the null hypothesis and conclude that there is no unit root on FDI. I conclude that FDI is stationary at level at $99 \%$ level of confidence.

The ADF statistic for Government expenditure is 2.029611 against a Mackinnon value of -3.5778 . Therefore I do not reject Ho and conclude that there is no unit root on government expenditure. I therefore conclude that government expenditure is stationary at first difference at $99 \%$ level of confidence. The ADF statistic for inflation is 9.266929 against the Mackinnon value of -3.5745 . I therefore reject the null hypothesis and conclude that there is a unit root on inflation; I also conclude that inflation rate is stationary at level at $99 \%$ level of confidence.

The interest rate has an ADF statistic of -2.062040 against a Mackinnon value of -3.5745 . I do not reject the null hypothesis and conclude that there is no unit root on interest rate. I also conclude that interest rate is stationary at level at $99 \%$ level of confidence.

I reject the null hypothesis and conclude that there is a unit root on external debt. I conclude that external debt is stationary at first difference at 99\% level of confidence. Net exports have an ADF statistic of -5.871179 with a Mackinnon value of -3.5778 . I reject Ho and conclude that there is a unit root on net exports. I conclude that net exports are stationary at first difference at $99 \%$ level of confidence. Lastly Private investment is stationary at level at $1 \%$. The ADF statistic is -4.382423 against a Mackinnon value of -3.5745 . I reject Ho and conclude that private investment is stationary at $99 \%$ level of confidence.

\section{Interpretation of results of regression}

Model 1

$\mathrm{GDP}=\alpha+\beta \mathrm{FDI}+\mathrm{E}_{\mathrm{t}}$

Table 4.1. shows the results of Regression (Appendix 3)

\begin{tabular}{ccccc}
\hline Variable & Coefficient & $\begin{array}{c}\text { Standard } \\
\text { Error }\end{array}$ & t-Statistic & Probability \\
\hline C & -0.035128 & 0.021080 & -1.666444 & 0.0102 \\
FDI & 3.282888 & 0.675655 & 4.858822 & 0.0000 \\
\hline
\end{tabular}

$\mathrm{R}^{2}=0.339158 \quad$ Adjusted $\mathrm{R}^{2}=0.324792$

DW Statistic $=0.429145$

F-Statistic $=23.060815$

Probability $=0.000014$

$$
\begin{aligned}
& \text { Model } 1 \\
& \text { GDP }=-0.035128+3.282888+E_{t} \\
& (0.021088) \quad(0.675655)
\end{aligned}
$$

The value of $\mathrm{R}^{2}$, that is, 0.339158 shows that $33.92 \%$ of variations in the GDP of Zimbabwe are explained by FDI. The remaining $66.09 \%$ is explained by other variables. The $66.09 \%$ is too large a figure so this has prompted I to come up with a better model that explains the GDP of Zimbabwe. The DW Statistic of 0.429145 is greater than adjusted $R^{2}$ (0.324792) showing that the regression is not spurious. The value of F- Statistic is 23.60815 and the probability is close to zero $(0.000014)$ showing that the exogenous variables 
are statistically significant thus have an impact on the

Model 2

Gross Domestic Product of Zimbabwe.

Table 4.2. below shows summary of regression results (Appendix 3)

\begin{tabular}{ccccc}
\hline Variable & Coefficient & Standard Error & t-statistic & Probability \\
\hline C & 0.002770 & 0.000284 & 9.765305 & 0.0000 \\
D(FDI) & 0.264254 & 0.013552 & 1.949795 & 0.0586 \\
D(GVT EXP,2) & 0.012311 & 0.024182 & 0.509082 & 0.0613 \\
D(Inflation) & -2.549369 & 0.056033 & -0.454979 & 0.0000 \\
D(Interest Rate) & -0.003171 & 0.005862 & -0.541058 & 0.0592 \\
D(External Debt,2) & -0.001631 & 0.005263 & -0.309888 & 0.7583 \\
D(Net Exports,2) & -0.002046 & 0.009150 & -0.223606 & 0.8243 \\
D(Private Investment) & 0.450077 & 0.203334 & 2.213489 & 0.0329 \\
\hline
\end{tabular}

$\mathrm{R}^{2} \quad=0.984867$

Adjusted $\mathrm{R}^{2}=0.982079$

DW Statistic $=1.181223$

F- Statistic $=35.32891$

Probability $=0.0000$

Model 2

$$
\begin{aligned}
& \mathrm{GDP}=0.0028+0.2643 \mathrm{FDI}+0.0123 \mathrm{GE}-2.5494 \mathrm{INFL}-0.0032 \mathrm{IR}-0.0016 \mathrm{ED}-0.0025 \mathrm{NE}+0.4501+\mathrm{Et} \\
& \begin{array}{llllllll}
(0.000284) & (0.01355) & (0.024182) & (0.056033) & (0.005862) & (0.005263) & (0.00915) & (0.213334
\end{array}
\end{aligned}
$$

The value of $\mathrm{R}^{2}$, of 0.984867 shows that $98.49 \%$ of variations in GDP of Zimbabwe are explained by a combination of variables in the model, that is,

$\mathrm{GDP}=\mathrm{f}\{\mathrm{FDI} ; \mathrm{GE} ; \mathrm{INFL}$;IR;ED;NE;PI;E $\}$.

The remaining $1.51 \%$ is explained by dummy variables. The main problem of the model is multicollinearity given by the tolerance of the data. A tolerance of less than 0.20 or 0.10 and/ VIF of 5 or 10 and above indicates a multicollinearity problem (O’Brien; 2007). If multicollinearity is perfect, the regression coefficients of the $\mathrm{X}$ variables are indeterminate and their standard errors are infinite, if less than perfect, the regression coefficients have large standard errors which mean that the coefficients cannot be estimated with great precision or accuracy.

Tolerance $=1-\mathrm{R}^{2}=1-0.984867=0.015133$

The Variance Inflation Factor $(\mathrm{VIF})=1 /$ tolerance

$$
=1 /\left(1-\mathrm{R}^{2}\right)
$$

$\mathrm{VIF}=1 / 0.015133$

$$
=0.6608
$$

This shows that multicollinearity is dominant in the data. Having identified the multicollinearity, I decided to take the do nothing method to resolve the problem (Gujarati D: 2004). The BLUE property of the OLS estimators come into play (Ibid: 2004)

The DW statistic is above the value of $\mathrm{R}^{2}$ and Adjusted $\mathrm{R}^{2}$. That is , the DW statistic is 1.181223 which is above the value of adjusted $\mathrm{R}^{2}(0.984867)$. This shows that the regression is not spurious. The $\mathrm{F}-$ Statistic is 35.32891 and the probability is Zero $(0.0000)$ showing that exogenous variables are statistically significant, thus have an impact on the GDP of Zimbabwe.

\subsection{Covariance and Correlation of variables}

Results from the covariance matrix (Appendix 4) and Correlation Matrix (Appendix 5) show strong co-moving between GDP and dependent variables. This shows that there is a high degree of association between GDP and explanatory variables. This is strong evidence to back up the model and conclude that all variables included in the model are valid regressors for the model.

The results extracted from Eviews 4(2) show that there is positive covariance on GDP versus FDI, Government Expenditure, Inflation and interest. However a negative comoving is visible between GDP and External debt, net exports, private investment. The degree of association is depicted by the correlation matrix.

There is strong positive correlation between GDP and FDI. The correlation coefficient is 0.582373 . This means that Gross domestic product and Foreign Direct Investment move in the same direction. When FDI increases, the will be a proportionate increase in GDP, the same applies when FDI decreases, the National Income (GDP) will also decrease by a proportionate figure.

There is also strong positive correlation between GDP and Government Expenditure, the correlation coefficient is 0.504791 . This shows the positive impact that government expenditure have on the country's GDP. A proportionate increase in Government expenditure will trigger a proportionate increase on the country's national income.

There is very strong negative correlation between GDP and Inflation, the correlation coefficient is -0.864193 . This shows that inflation is the main enemy of the economy. When inflation rises, GDP will fall by more than 
proportionate amount.

There is strong negative correlation between GDP and Interest rate, the correlation coefficient is -0.696561 . There exist strong negative correlation between GDP and external debt, the correlation coefficient is -0.627944 . There is weak negative correlation between GDP and net exports. The correlation coefficient is -0.471194 . A very strong negative correlation exists between GDP and private investment, the correlation coefficient is -0.781092 .

All in all, the variables have shown some association with the dependent variable, with some showing very strong/negative correlation with the dependent variable. This shows that the independent variables influence the behavior of the explained variable at any given point in time.

\subsection{Comparing Regression, Correlation and Covariance}

Table 4.3. shows a comparison of the regression, Correlation and covariance

\begin{tabular}{cccc}
\hline Variable & Regression & Correlation & Covariance \\
\hline FDI & + & + & + \\
Government Expend. & + & + & + \\
Inflation & - & - & + \\
Interest Rate & - & + & + \\
External Debt & - & - & - \\
Net Exports & - & - & - \\
Private Investment & + & - & - \\
\hline
\end{tabular}

There is clear depiction that FDI positively influence GDP. This is shown by positive regression coefficient $(\beta)$, positive correlation coefficient and a positive covariance. The results from the table leaves no room to doubt that government expenditure impacts positively on GDP, there is positive regression coefficient, positive correlation coefficient and positive covariance. Conflicting inferences were found on Inflation and interest rate. The former have a negative regression coefficient, a negative correlation coefficient but a positive covariance. The later have a negative regression coefficient, a positive correlation coefficient and a positive covariance. Evidence gathered show that External debt negatively impact on GDP. All indicators are negative, which is, regression coefficient, correlation coefficient and covariance. Net exports have a negative impact on GDP of Zimbabwe. Conflicting results are appearing on private investment, evidenced by a positive regression coefficient and a negative covariance.

\section{Discussion of Variables}

\subsection{Gross Domestic Product and Foreign Direct Investment}

Since the first model could not be relied upon, the results of the second model were used to deduce inferences. On the second model, there is sufficient evidence of a positive relationship between GDP and Foreign Direct Investment. The elasticity of GDP with respect to change in FDI is 0.264254 showing that a $1 \%$ increase in FDI will result in
$26.4 \%$ increase in GDP. The results are in line with the theoretical predictions of Balasubramanyam et al (1996), Gatsanaga (1998) to mention a few. The t-statistic of 1.949795 supports the hypothesis that FDI account for a larger portion of the Zimbabwean GDP. The probability of rejecting the null hypothesis (Ho: FDI does not affect GDP) when it is correct is zero (0.0000). This shows that the chances of making an inferential error are very slim. The correlation coefficient of 0.58 is large enough to conclude that there is strong positive correlation between GDP and FDI. I therefore conclude that an increase in FDI in Zimbabwe will result in an increase in GDP by a larger margin.

\subsection{GDP and Government Expenditure}

There is a positive relationship between government expenditure and GDP in Zimbabwe. This explains government funded entrepreneurship in Zimbabwe. The elasticity of GDP with respect to change in government expenditure is 0.012311 showing that a $1 \%$ increase in government expenditure will increase GDP by $1.23 \%$. An increase in government expenditure will increase Economic Growth which is in line with theoretical predictions of John L. (2004) but it contradicts with the findings of Carvins (1993) in Nigeria. The t-statistic of 0.509 supports the hypothesis that government expenditure will increase GDP. This is coupled by a very low probability of 0.0613 which shows that the probability of making a decision error by rejecting Ho when it is correct is approximately equal to zero $(0,0613)$ thereby validating the regression results.

\subsection{GDP and Inflation}

The elasticity of GDP with respect to inflation is -2.55 showing that a $1 \%$ increase in inflation will result in $255 \%$ decline in GDP. This is in line with conclusion of Bitten Court et al (2010) which says that high inflation contributes to macro economic uncertainty which negatively affects investment and consequently economic growth. The tstatistic of -0.455 supports the hypothesis that inflation have negative impact on GDP. The probability is 0.0000 showing that the likelihood of rejecting Ho when in fact it is true is Zero.

\subsection{GDP and Interest Rate}

The results show that there is a negative relationship between GDP and interest rates. The elasticity of GDP with respect to interest rate is -0.003171 . This means that a $1 \%$ increase in interest rate may result in a fall in GDP by $0.3 \%$. This is in line with the predictions of Ben Bernanke (2006) and Emery R. F(1971) where he said that interest rate is the price paid for capital, thus its increase results in shortage of capital thereby constraining growth prospects. The tstatistic is -0.541058 supports the hypothesis that interest rates have a negative impact on GDP, the probability of rejecting the Ho when it is true is 0.0592 , which is very low and thus I can rely on his results. 


\subsection{GDP and External Debt}

The results are inconclusive for the impact of external debt on GDP. The elasticity of GDP on External debt is very low. The probability of making an error is too high (0.7583). Thus the likelihood of rejecting Ho when it is correct is very high. This makes the inference null and void. This contradicts with theoretical predictions which say there is a negative impact between external debt and GDP (Amaoteng K; 1996) and Claessens (1996).

\subsection{GDP and Net Exports}

The results show that Economic Growth in Zimbabwe is irresponsive to changes in net exports. The probability of rejecting Ho when it is correct is very high $(0.8243)$ coupled by a very low t-statistic. There is very high probability that net exports may be insignificant. This is in line with the conclusions made by Sivio L(2008).

\subsection{GDP and Private Investment}

There is sufficient evidence that private investment affect GDP in Zimbabwe. The elasticity of GDP with respect to Private 1 nvestment is 0,450077 showing that a $1 \%$ increase in private investment result in $45 \%$ increases in GDP. The tstatistic is large enough (2.213489) which supports the hypothesis that private investment positively affect the GDP of Zimbabwe. The probability of rejecting the null hypothesis when it is true is zero $(0.0000)$ showing that there is strong evidence that there is a positive impact.

\subsection{Summary of Findings}

Chapter four of the research have analyzed seven independent variables which are FDI, Government expenditure, Inflation, Interest Rate, Net Exports, External Debt and Private Investment. The findings were as follows:

$\mathrm{GDP}=-0.35128+3.28 \mathrm{FDI}+\mathrm{Et}--$ (1)

$\mathrm{GDP}=0.0028+0.26 \mathrm{FDI}+0.021 \mathrm{GE}-2.55 \mathrm{INFL}-$ $0.003 \mathrm{IR}+0.45 \mathrm{PI}+\mathrm{Et}$

External Debt and Net Exports have been excluded from the equation because the data has proven to be inconclusive. I's findings were as follows:

- A $1 \%$ increase in FDI result in $26 \%$ increase in GDP. Results from the Correlation matrix shows that there is strong positive correlation between FDI and the Gross Domestic Product.

- A $1 \%$ increase in Government expenditure result in $1.2 \%$ increase in GDP. There is strong positive correlation between government expenditure and economic growth.

- A $1 \%$ increase in inflation results in a $255 \%$ decrease in GDP. There is very strong negative correlation between inflation and FDI.

- A $1 \%$ increase in interest rate result in $0.3 \%$ decrease in GDP. There is negative correlation between Interest rate and GDP.

- The results were inconclusive on the impact of
External debt on GDP. There is a strong negative correlation between External debt and GDP. The results were drawn from the correlation matrix.

- The results were also inconclusive for the impact of Net Exports on GDP. A week negative correlation was found between Net exports and Economic growth.

- A $1 \%$ increase in private investment result in $45 \%$ increase in GDP. A strong negative correlation was found on the results obtained from the correlation matrix.

\section{Research Conclusions}

I conclude that the null hypothesis for both models does not hold.

Evidence gathered in this paper shows that there is significant positive relationship between FDI and GDP. An increase in FDI would yield an increase in GDP. Thus an increase if FDI by $1 \%$ result in an increase in GDP by $26.4 \%$. I am therefore convinced that FDI is the key to the increase in Zimbabwean GDP. FDI involves building factories, setting production lines; managerial skill improvement and expertise, thus an increase in FDI will have a ripple effect on other key drivers of the economy.

There is significant positive relationship between GDP and Government Expenditure. Thus the government should continue to provide financial support to key sectors of the economy such as SMEs. This means that the resources that the government channels towards economic improvement have a positive impact on economic growth.

There is a significant negative relationship between inflation and GDP. Inflation results in macroeconomic uncertainty that affect other engines of growth in the economy.

There is statistically significant negative influence on the increase of Interest Rates on GDP. Interest rate is the price paid by borrowers, if it increases; GDP tends to fall because the cost of capital would be too high for key players in the economy.

There is statistically significant positive relationship between GDP and private investment. An increase in private investment tends to result in an increase in GDP.

The results for the impact of external debt and Net Exports on GDP merit further investigations. There is no sufficient evidence of the importance of the two variables in explaining the level of the GDP. The probability of rejecting the null hypothesis when it is correct is too high for I to make a conclusion. Therefore the results are statistically insignificant.

\section{Policy Recommendations}

In light of the conclusions made about GDP and its determinants, the following policy recommendations were made;

Government policies should seek to attract FDI if Zimbabwe intends to meet its growth targets. Fostering an 
attractive political and socio-economic environment will create the much needed investor confidence that will see the flow of FDI into the country.

The fiscal policy of the country should seek to address capital shortages in the key sectors of the economy. Thus a large section of government expenditure should be channeled towards the productive sectors of the economy in order to increase GDP.

The government should implement policies that keep inflation levels at minimal. Inflation has proven to have the largest negative impact compared to other variables. Policies that curb inflation will stabilize the economy and reduce economic uncertainty.

The government through the ministry of finance and the Reserve bank should try to control the lending rate of financial institutions and micro finance institutions. Putting a ceiling on the acceptable rate of interest that can be charged will reduce the cost of capital thereby increasing accessibility of funds which in turn increases the national income (GDP)

Private investment also makes a large contribution to GDP. Policies that create investor confidence will increase GDP by a very large percentage. Certainty about the return that will be obtained from the investment is the major inducement for investment; as such those investor friendly policies will improve GDP.

\section{References}

[1] Amaoteng, K and Amoako-Adu, B. (1996)."Economic growth, export and external debt causality: The case of African countries". Chapman and Hall: Applied Economics, vol. 28, pp. 21-27

[2] Badawi, A. A. (2003) "Private Capital Formation and Public Investment in Sudan: Testing the Substitutability and Complementarities Hypotheses in a Growth Framework", Journal of International Development, Vol.15, No. 6,pp.783799.

[3] Balasubramanyam, V.N, Salisu, M., and Sapsford, D., (1996) Foreign Direct Investment and Growth in EP and IS countries, Economic Journal, 106, 92-115.

[4] Bayai, I. and Nyangara, D. (2013) An analysis of determinants of private investment in Zimbabwe for the period 2009-2011, IJEMS, vol.2, No.6, 2013

[5] Bitten-Court, M. (2010) Inflation and Economic growth in Latin America: Some panel time series evidence, University of Pretoria.

[6] Boreinsztein, E.J. and Gregorio, J.E (1998), How does foreign direct investment affect Economic growth “ Journal of International Economics 45, : 115-135.

[7] Bloomstom, M., Lipsey R.E., and Zegan M (1992), "What Explains Developing Country Growth?" National Bureau of Economic Research Working Paper, Vol 9, February, pg 4132 .
[8] Claessens, S. C. (1990) The Debt laffer curve: Some Empirical Estimates. World Development, Vol. 18 No. 12

[9] Clarke, D. G., (1980) Foreign Companies and International Investment in Zimbabwe. Catholic Institute of International Relations, London.

[10] Dickey, D and Fuller, W (1979), "Likelihood Ratio Statistics for Autoregressive Time Series with a Unit root" Econometrica, 49, 1057-1077.

[11] Elbadawi, A. I., J. B. Ndulu., and N. Ndung'u (1996), "Debt overhang and economic growth inSub-Saharan Africa". A paper presented to the IMF/World Bank conference on External Financing for Low Income Countries in December

[12] Findlay, R, (1978) Relative backwardness, foreign direct investment and the transfer of technology. A simple dynamic model, Quarterly Journal of Economics, 92, 1-16.

[13] Greyhill Advisors (2011). US FDI and Site Selection. http://greyhill.com/2011/10/13/us-fdi-and site-selection.html.

[14] Gwenhamo, F. (2009) Foreign Direct Investment in Zimbabwe. The role of Institutional factors, August 17, 2009. ERSA Working Paper 112, Economics Research Southern Africa, Cape Town.

[15] Hirschman, A. (1958) The strategy of economic development. New Haven; Yale University Press.

[16] Jechere, P. (2011) Investment and Growth Relations. An empirical assessment in Zimbabwe, University of Zimbabwe, International Journal of International Business and Cultural studies.

[17] Mankiw N. G (1992) Acontribution to the empirics of economic growth. The quarterly journal of economics 107(2), 407

[18] Pavin C (1953) Full capacity vs full employment Growth; Quartely Journal of economics, vol. 67(4), pp 545 - 552

[19] Rodriguez - Clare, A. (1996). "Multinational linkages and Economic Development." American Economic Review 86: $852-878$

[20] Tinbergen J (1942) Zur theories der langsfristigen wirschaft sent wicklung" weltwirtschaftliches Archiv vol. 55, p. 511 49. Translatedn1959 in L. H Klaassens, L. M. Koyok and H. J Witteveen, editors. Jan Tinbergen, Selected papers. Amsterdam.

[21] Tobin, J (1955) A dynamic aggregative model, Journal of political economy, vol 63(2) pp $103-15$.

[22] Tomas, H. and Zuzara, I. (2011). Determinants of horizontal spillovers from FDI. Evidence from a large meta-analysis, "working paper 2011/07, Czech National Bank, Research Department.

[23] UNCTAD, 1999, " Trends in international investments agreements: An overview", UNCTAD Series on issues in international investments Agreements. 